\title{
Implementation of Superior Rubber Seeds Program as A Community Empowerment in the North Kayong District West Borneo
}

\author{
Dedi Kusnadi Pardi* \\ Department of Public Administration, Faculty of Social and Political Science \\ Tanjungpura University, Pontianak Indonesia
}

\begin{abstract}
This research has in mind to find out and analyze the government policies namely Minister of Agriculture Regulation Number: 04/Permentan/OT.140/I/2009 concerning Guidelines for Managing Social Assistance Funds for Agriculture. The method used in this research is qualitative, supported by descriptive research. The results showed that the implementation of a superior rubber seeds assistance policy in the North Kayong District was influenced by communications, resources, disposition, and bureaucratic structures. The communication that was performed while executing a superior assistance program was not properly performed. Factors affecting resources are the minimum number of field extension officers to advise and assist farmers in the management of superior rubber seeds, no suitable facilities and infrastructures are available yet, in particular fertilizers and medicines, as well as adequate funding and impact on the fulfilment of facilities, infrastructure, and operational field officers. From sources of information, there is a factor that rubber farmers do not have enough information to properly manage seeds' assistance. Disposition of policy implementers has been very good in providing assistance and counseling but the results are not optimal due to the limited number of officials and were not supported with adequate incentives. The bureaucratic structure in implementing the superior rubber seeds assistance program in Rantau Panjang Village, Simpang Hilir District looks good as there is no long-range of controls and the procedure for submitting assistance is not too complicated. The recommendations of this research are increasing the number of field extension workers, increasing the budget allocation for superior rubber seeds assistance programs under the needed, increasing the commitment of officers by providing additional incentives according to workload. The importance of these farmers' self-help so that they have a sense of belonging to this program.
\end{abstract}

Keywords: Implementation, Agricultural Social Assistance

DOI: $10.7176 / \mathrm{PPAR} / 10-5-04$

Publication date:May $31^{\text {st }} 2020$

\section{Introduction}

As a country that adheres to the concept of a welfare state, the Government of Indonesia continues to carry out development in all fields to create a prosperous and equitable society in agriculture or plantations. The development of economic competitiveness is carried out through increased efficiency, modernization, and added value of agriculture in a broad sense to be able to compete in the local and international markets and to strengthen the national production base. This is done to improve the welfare of farmers by developing dynamic and efficient agribusinesses by involving the active participation of farmers and business people in agriculture. Besides, it is also expected to create a diversification of the people's economy which in turn can increase the contribution to the economic growth of farmers.

The condition of smallholder rubber plantations is very concerned, the area of plantations for rubber plants that are still largely empty, the presence of old local rubber plants that are damaged, and very significant, thus reducing production and productivity. The above situation requires special attention to find the root of the problem and then take action through relevant programs and activities.

The development of rubber plantations has provided an important role for the national economy, namely as a source of foreign exchange, a source of industrial raw materials, a source of income and community welfare as well as the development of regional economic growth centres and at the same time play as a role in the preservation of environmental functions. Since the implementation of regional autonomy, rubber plantations for some regions in Indonesia have become a prima donna sector to increase regional income and improve the welfare of the community especially farmers.

The rubber plant is also an annual plant that can provide benefits in environmental preservation, especially in terms of $\mathrm{CO} 2$ absorption and $\mathrm{O} 2$ production, even in the future the rubber plant is a potential source of wood that subsidizes the needs of natural forest wood from year by year, but its availability is declining. The development of rubber plantations carried out in non-new areas has proven to be a driving force for regional economies with various multiply effects. Empirical data proves that the development of rubber plantations in new areas that were previously isolated has developed.

During this time, there have been many attempts made by the Indonesian government in the framework to 
improve the welfare of rural farmers. This policy was implemented because of it the fact that the majority of Indonesians living in rural areas are still classified poor and depend on their lives from natural generosity in the agricultural sector. One of the efforts made by the government to improve the welfare of farmers in the countryside is through the development of smallholder rubber plantations. As a new autonomous region, the North Kayong Regency Government continues to strive for development in various fields of life. The development is carried out by relying on the superior sectors found in Kayong Utara Regency.

One of the potential plantation sectors that have the prospect of being developed as strength of the people's economy is rubber plantations. Currently the rubber community has become one of the mainstay sectors of the North Kayong Regency. Considering such a large role, the rubber community has been established as one of the leading plantation commodities in the North Kayong Regency.

The condition of smallholder rubber plantations in the North Kayong Regency is mostly local rubber and its age is old which affects its productivity. As a manifestation of the seriousness of the North Kayong Regency government in improving the rubber plantation sector to improve the welfare of the farming community. The government issued a rubber seeds assistance program. This program is based on the Minister of Agriculture Regulation No. 04 / Permentan/OT.140/I/2009 concerning Guidelines for Managing Social Assistance Funds for Agriculture, where the technical implementation of superior rubber assistance is outlined in the Budget Implementation List of the North Kayong Regency Forestry and Plantation Office Work Unit.

The superior rubber seeds assistance program is a government program in the form of direct grants of certified superior rubber seeds, to improve the age composition of productive rubber plants, increasing plantation productivity and increasing farmers' income and welfare in North Kayong Regency.

In 2011, rubber seedlings also came from the Ministry of Development of Disadvantaged Regions, which was distributed in Teluk Batang on 125 hectares of land and Simpang Hilir (25 hectares). Furthermore, the assistance from the Regional Government Budget of West Kalimantan Province which is allocated to Maya Island (25 hectares), Seponti (175 hectares), Simpang Hilir (125 hectares), and Sukadana (75 hectares). Of the total area that has been helped by the North Kayong Regency government through the Forestry and Plantation Service as a Stake Holder $99 \%$ of the superior rubber seeds can be absorbed well by farmers and $1 \%$ biased due to natural factors that are less supportive when distributing the rubber seeds.

Based on previous research shows that rubber seeds assistance activities provided by the North Kayong District Government have not been effective. It can be seen from the communication aspect, the rubber seedlings assistance program has not been well communicated to the implementor and the farmers as the target group. There are still implementors from the North Kayong District Forestry and Plantation Office who do not yet understand the technical implementation of activities such as seed distribution and guidance or assistance to farmers. The same thing can also be seen from the understanding of the farmers about the purpose and objectives of the program and how to implement the program, especially in maintaining seeds. The lack of knowledge of farmers about more modern rubber cultivation with the help of a good agricultural system is not matched by increased in counseling by field extension workers.

In addition to communication difficulties, the implementation of a superior rubber seeds assistance program in the Simpang Hilir District continues to face a lack of resource support, such as operational resources for officers, so that officers often complain about the lack of transportation costs. While for farmers' groups they do not receive financial support for the purchase of fertilizers and medicines, because there are still no production facilities and infrastructure support, fertilizers, and medicines to carry out maintenance on the aid of the seeds supplied.

The implementation of the superior rubber seeds support program for farmers in the Simpang Hilir District requires significant support from the government, in particular from the Forestry and Plantation Service. So far it seems that the support and commitment of the government are still not optimal, as evidenced by the lack of periodic and ongoing supervision and assistance by officers regarding the technical preparation of seeds, planting, and maintenance so that rubber farmers lack information about both cultivation and garden management.

The next problem is related to the structure of the bureaucracy. The process of distributing seeds to the farmer groups must meet several requirements, namely that farmers must be prepared with land for planting. In this case, there is still approximately 20 percent of farmers who are not ready to plant land for planting rubber but have received assistance in the sense that the land they own is still in the form of forest and it is not yet ready to be planted with rubber resulting in the sale of other parties.

Based on the problems mentioned in the background, the researcher is interested in conducting further research on the implementation of superior rubber seedlings assistance programs to find out and reveal the program implementation process following the provisions to be achieved

\section{Public Policy}

According to Anderson (in Islamy, 2001: 17), a policy is a series of actions with specific objectives that are followed and executed by an actor or group of actors to solve a certain problem. This view emphasizes that real policy is being taken to find solutions or solutions to problems that arise. It can also be explained that the policy 
is based on problems that must be solved immediately in order not to give a bad impact.

According to Lasswell and Kaplan (in Abidin 2002: 19) policy as a project that is projected of goals, values, and practice. Subsequently, Heglo (in Nugroho, 2003: 15) said the policy as "an action intended to achieve certain goals (an activity intended to achieve a certain goal).

Meanwhile according to Mustopadidjaja (2002: 5) public policy is basically "a decision that is intended to overcome certain problems, or to achieve the goals carried out by the competent agencies in the framework of carrying out the tasks of state government and development. In the life of state administration, formally this decision is usually outlined in various forms of legislation ". Then public policy can be formulated as a decision taken by the government, to overcome certain problems or to achieve certain goals carried out by the competent agencies in the framework of carrying out the tasks of government and development as outlined in the form of legislation.

Policy implementation is an activity that determines whether a policy is successful or has barriers that are even rejected by the target group (stakeholders). In line with this, Wahab (2002: 59) argues that the actual implementation of the policy is related not only to the mechanism of translating political decisions into routine procedures through bureaucratic channels but even more to who gets what from a policy. Therefore, policy implementation is the most important aspect of the entire policy process. Winarno (2007: 143) states that policy implementation is a crucial phase in the public policy process. a policy program must be implemented in such a way that it has the desired impact or objectives.

Another view of Mazmanian and Sabatier (in Widodo, 2007: 88) explains the policy implementation process in more detail by stating that implementation is the implementation of basic policy decisions, usually in the form of laws, but also in the form of orders or decisions by key executives or decisions by judicial authorities. Mazmanian and Sabatier further said that the decision generally identifies the problem to be solved, clearly identifying the goals or objectives to be achieved, and different ways to structure or regulate the implementation process.

Pressman and Widavsky (in Purwanto \& Sulistyastuti, 2012: 20) interpret the implementation with several keywords, namely to carry out the policy (to carry out), to fulfill the promises as stated in the policy document (to fulfill), to produce output as stated in the policy document (to produce), to complete the mission that must be realized in the policy objectives (to complete)

Building on the above opinion, it can be concluded that the implementation of the policy is an action that is taken after a policy has been adopted by intervening. In other words, implementation is an intervention itself, with the aim that the policy can achieve the set goals. Policy implementation is an activity seen after giving legitimate direction from a policy, including efforts to manage inputs when producing outputs or results for the community over time.

Policy implementation is often ineffective, according to the Edward III Policy Implementation Model (in Winarno, 2007: 125), there are four types of factors that influence the effectiveness of policy implementation. These factors or variables are communication, resource, tendencies or behavior, and bureaucratic structure. The explanation of each variable is:

a. Communication variable

Without proper communication, all plans, rules, decisions, or concepts carefully designed will not be recorded, digested, or processed by subordinates. High-quality information is required in both policymakers and implementation. Because high-quality information will determine the effectiveness of the implementation.

b. Resource variable (resources)

Policy sources are factors that directly influence the effectiveness of policy implementation. A policy, however well formulated, is backed by strong legal or regulatory instruments, but if it is not backed by the availability of sufficient resources, whether in the form of funds, equipment, technology, and other facilities and infrastructure, it is difficult to implement.

c. Tendencies factors.

According to Winarno (2007: 134), the tendency (disposition) is a factor that has important consequences for the implementation of the policy. In the implementation of the policy it is necessary to support the implementation apparatus which is of high quality and highly committed to the program implementers.

d. Bureaucratic structure factor.

The bureaucratic structure responsible for the implementation of the policy has a significant impact on the implementation of the policy, Repley and Franklin (in Winarno 2007: 149) reveal that there are six characteristics of the bureaucracy, being chosen as a social tool to overcome political problems, the dominant institution in implementing the policy, aims otherwise, in a wide and complex environment, with the ability to survive and the bureaucracy has both autonomy and the ability to negotiate. According to Edward (in Winarno, 2007: 151), Standard Operating Procedure (SOP) and fragmentation are the two main features of bureaucracy. SOP is an internal response to the limited time and resources of 
implementation and the desire for uniformity in work, while fractionation is external pressure.

The policy carries the risk of failure in the sense that the policy fails to achieve its objectives. Hogwood and Gunn (in Wahab, 2002: 61) have divided the notion of policy failure into two categories, namely: NonImplementation and Unsuccessful Implementation. According to Wahab (2002: 62) what is meant by not implemented means that:

A policy is not implemented according to plan, maybe because the parties involved in the implementation do not want to cooperate or they have worked inefficiently or not fully mastered the problem. Whereas an unsuccessful implementation usually occurs when a policy has been implemented according to plan, , but given the external circumstances turned out to be unfavorable (for example, a change of power, natural disasters).

In connection with the things stated above, the process of implementing the policy needs careful attention; during implementation there are often obstacles that can lead to the failure to achieve the set goals.

To analyze the problems in the implementation of the superior rubber assistance program, researchers used the theory of the implementation of Edward III policy. According to Edward III, there are 4 variables that influence policy implementation, namely communication, resources, disposition, and bureaucratic structure. The communication variable shows how communication is performed in the program, such as how the program is transferred, program clarity, and consistency in the communication of the program. In the variable resources will be seen as support for facilities and infrastructure, human resources, information, funding for the current program. The disposition variable describes how the support and motivation of officials for implementation of the program, how the response to the program is support or vice versa. Regarding the variable bureaucratic structure, will be described about the bureaucratic structure of the Forestry and Plantation Service, the willingness to implement instructions and technical guidelines, and program procedures that are in line with the objectives and the policy environment.

\section{Research Method}

This research used exploratory research. According to Sugiyono (2007: 9), exploratory research is a research that aims to answer the questions that have been formulated and in general this research does not use a hypothesis, so in this research only provided a factual explanation on issues related to aspect research by researchers.

In determining informants/subjects, researchers use a purposive technique, which is a technique for determining the source of information for specific purposes only, which means that the chosen people are those who know clearly about the issues raised (Sugiyono, 2007: 62). Following these techniques in determining informants, the authors establish the criteria as a program implementer, mastering and understanding the process of implementing superior rubber assistance programs that are within the scope of the Forestry and Plantation Service. While outside the scope of the Forestry and Plantation Service, the selected informants are the farming communities that receive superior rubber assistance and included in the farming groups.

Data collection techniques in this research such as observations, interviews are conducted through in-depth interviews, and documentation studies are carried out to broaden insights and deepen the understanding and perceptions of researchers towards the program being implemented.

The analysis technique used in this study is descriptive qualitative analysis. This data analysis technique interprets and describes data that have been systemically and systematically collected. Interactive data analysis by Miles and Huberman (1992: 16) is used to present the data so that it is more meaningful and easier to understand.

Data collection is placed as a component that is an integral part of data analysis activities. Data analysis is performed from the start of the research activities to the end of the research. In this model, the analysis activities are divided into 3 phases, namely data collection, data reduction, data presentation, and concluding.

\section{Research Result}

Based on the results of field research conducted by the research team, greetings of approximately 5 months at the study site. The following will present the results of research related to factors that influence the effectiveness of the implementation of superior rubber assistance policies as a form of community empowerment in the Kayong Utara Regency.

\subsection{Communication}

The communication factor is an important aspect that can influence the implementation of the policy. The communication referenced in this study is the extent to which the content of the policy, namely superior rubber assistance can be properly communicated to those who will be involved as program implementers, and to those who are members of farmers groups as target groups of the program. To analyze communication when implementing a superior rubber assistance program in the Simpang Hilir District, there are 3 (three) aspects that the researcher will analyze one by one, as stated by Edward III. The three aspects include transmission, clarity, and consistency. 


\section{a. Transmission}

Concerning communication in the Superior Rubber Assistance Program by the North Kayong District Forestry and Plantation Office in Simpang Hilir District, from the interview with the Head of the North Kayong District Forestry and Plantation Office, the following information was provided: "Superior Rubber Support is the North Kayong District Forestry and Plantation Service Office which in this case assist in the form of superior rubber seeds to farmers, therefore socialization is carried out directly through the field of production and protection of North Kayong District Forestry and Plantation Service Office by involving field officers in farmer groups in every village that receiving assistance."

Based on the results of the interview, it appears that the socialization of a superior rubber assistance program was carried out directly by not going too much through different levels of government, namely directly to the farmers as the target of the policy group. This has a positive impact on the provision of information to farmers when the information they receive comes directly from the party that issued the program. The process of communicating superior information about the rubber assistance program given directly to farmers is certainly helpful in getting clear information and in avoiding misunderstandings among farmers because the information received is not interrupted.

Meanwhile, the results of interviews with field officers from the superior rubber assistance program Simpang Hilir District explained the program's socialization process as follows: "From what I see the rubber seeds assistance program has been well communicated directly to farmers, farmer groups are getting a direct explanation from North Kayong District Forestry and Plantation Service officers and farmers received the explanation well. "

The results of the interview illustrate that the communication of the rubber seeds assistance program to farmers in the Simpang Hilir District has been well transferred to the farmers. However, as they are located in the sub-district and village areas, the involvement of the Sub-District Head and the Headman is also very important to obtain information on superior rubber assistance programs, although they were not actively involved in the implementation of activities, the program is being implemented or carried out by farmers who received assistance.

Regarding the involvement of the Simpang Hilir Sub-district government, from the results of the interview of researchers with the Simpang Hilir Sub-District Head stated: "Organically the superior rubber assistance program was implemented directly by the farmer groups under the North Kayong District Forestry and Plantation Service and the district and village governments were only involved during the socialization program. In addition, the Sub-District Head also signed a proposal submitted by the farmer group, the sub-district government also monitored that the program runs well and provides benefits for farmers to improve the family economy.

Based on this information, it illustrates that the sub-region government was not actively involved in promoting the superior rubber subsistence program for farmers, and was only to sign proposals for farmer groups.

\section{b. Clarity}

The communication received by those implementing the policy must be clear and not confusing (ambiguous). Unclear policy messages always impede implementation at certain levels, for which the implementers need flexibility when implementing policy. On the other hand, however, it will mislead the objectives of the adopted policy. In the rubber seeds assistance program in Simpang Hilir District, information about the program should be clearly communicated to both the program implementer and the farmers as well as the program target group. This clarity concerns the background of the program, program objectives, program benefits, program mechanisms, requirements to follow the program and other technical matters to be communicated to field officers and the farming community in Simpang Hilir District.

North Kayong Regency Forestry and Plantation Service Head said: "In my opinion, the superior rubber assistance program is clearly socialized for field officers and farmer groups in Rantau Panjang Village, Simpang Hilir District, this can be seen from distribution to planting by farmers who have already well ".

The results of the interview illustrate that the superior rubber assistance program has been well and communicated to farmer groups, which can be judged by the fluency of the stages of the program. To find out how far the information regarding superior rubber assistance program was received clearly by farmers in Rantau Panjang Village, the researcher interviewed with the Chair of the Farmer Group to give the following explanation: "I think the superior rubber assistance program is quite clear and well received by the community, and the community is very supportive of this program. However, I also admit that not all villagers understand how to concerning the management of superior rubber seeds because so far the community has only planted local rubber plants.

Based on the explanation from the Farmer Group chairman, it shows that the farming community generally sees that the superior rubber assistance program is quite clear in its purpose and objectives as well as in the benefits to farmers. However, for the sake of clarity in the implementation of the program, which is maintaining and planting superior rubber seeds, it is not all understood by the villagers.

Regarding the fact that not all villagers understand how to manage seeds that have been provided by the North Kayong District Forestry and Plantation Office, researchers conducted interviews with field officers who served in Rantau Panjang Village, while the information delivered by field officers was as follows: "basically the 
community supports and enthusiastic about this program, moreover the assistance provided is free and is a superior seed of PB 260 recommended clones, but at the time of planting there are still farmers who mistakenly treat these superior seeds, this is understandable because the villagers are more accustomed to growing local rubber. We as field officers do indeed provide counseling and assistance to farmers, but duet o the limitation of extension workers, assistance cannot be carried out optimally to all farmers.

Based on information conveyed by field officers in the superior rubber assistance program in Rantau Panjang Village, Simpang Hilir District, it was shown that not all communities received clear information about the superior rubber assistance program, especially on how to properly manage seedlings. Different from the local rubber that has been cultivated by the village community, superior seedlings do require special treatment by farmers, and to foster farmers' understanding of the management of these seeds must be carried out maximally and continuously by field officers.

The problems related to the lack of intensive socialization by field officers are more due to the minimal number of field officers owned by the Forestry and Plantation Office to provide counselling to farmer groups. Besides, the condition of the village infrastructure where this policy took place made it difficult for extension workers to reach it.

Based on the explanation, it shows that in the delivery of information the superior rubber assistance program has not been fully implemented until the understanding of the farming community in managing seed assistance from the Forestry and Plantation Service of North Kayong Regency. Clarity on how to manage seeds must be owned by all farmers who get assistance, because the seeds assistance program will show results when the seeds provided can be planted, well cared for, and bloom to the right age to be tapped by farmers. If there is a lack of care or poor treatment, rubber seedlings will not grow well, even though the assistance provided is superior seeds.

\section{c. Consistency}

One aspect of communication about implementation instructions is the issue of consistency. Conflicting decisions will confuse and hinder administrative staff and impede their ability to perform their duties effectively. The command given when implementing a communication must be consistent and clear (to be implemented or executed) because if the given order changes often, it can confuse the implementer in the field.

In an interview with the head of the North Kayong District Forestry and Plantation Office, information was obtained that: "All provisions in the superior rubber assistance program have been clearly and consistently communicated, there is no field implementation in violation of the established provisions "So far, there are no changes to confuse officers in the field."

The results of the interview show that the superior rubber seeds assistance program support has been consistently communicated to officers in the field and also to the beneficiary farming community. In other words, since the program was implemented by the Kayong Utara District Forestry and Plantation Office, there has been no change in the rules or forms of assistance provided. In this program, the assistance offered is superior rubber seeds and assistance in fertilizers and medicines. There is no assistance in the form of money to farmers.

Consistent or whether the information conveyed, of course better known by field officers and farmer groups who receive assistance. In the interview with the field officer, he provided the following information: "In my opinion, there has been no change from the Forestry and Plantation Office in the assistance program for superior rubber seeds so far; all consistent with what was programmed from the beginning."

The results of the interviews with field officers and the Head of farmer groups are consistent with the information provided by the head of the North Kayong District Forestry and Plantation Service. This shows that the superior rubber seeds assistance program has been communicated consistently so that it does not interfere with the smooth execution of the program. Consistency in the provision of information in this program is very important as it will promote community confidence and support in the seriousness of the North Kayong government in implementing a superior rubber assistance program.

\subsection{Resources}

In this research, there are several aspects of resources that will be analyzed in the implementation of superior rubber assistance programs, namely human resources, facilities and infrastructure, financing, and information. The results of research on these sources are described as follows.

\section{a. Human Resources}

When analyzing human resource factors in agricultural expansion, researchers will analyze them from two aspects, namely quality and quantity. From the quality aspect it should be recognized that high quality assisting officers or educators have mastered the problem of planting superior rubber. Therefore, the assistant officer needs strong support from research institutions that produce information and extension institutions that further process and study the information before passing it on to the farmers. To ensure that the instructors understand the information to foster sustainable farmer groups, the instructors must always receive training.

Regarding human resources in the implementation of a superior rubber assistance program in the Simpang Hilir District by the Forestry and Plantation Service Office of North Kayong Regency, based on the results of 
interviews with researchers, said the head of the Forestry and Plantation Service North Kayong District Office: "In Implementing superior rubber assistance program for farmers in North Kayong Regency, The North Kayong Regency Forestry and Plantation Office has prepared field officers in each sub-district to assist farmer groups who receive assistance so that farmers can plant seeds properly, not as long as they are planting because superior seeds require special treatment. So far, in my opinion, the number of field officers for assistance is still not optimal depending on needs, which has a major impact on the activities of assistance to farmers. Especially the inadequate village infrastructure.

Based on the results of the interview, it appears that the workforce supporting a superior rubber assistance program in the Simpang Hilir district is not in line with needs, which means that the number of field workers is still not appropriate or proportional to the number of farmers need help, not to forget whether it is related to the distance between villages in one district.

The results of interviews with field officers explain the number of field officers to provide assistance to farmers receiving superior rubber seeds, namely: "The number of field officers to assist and advise is still lacking, to provide assistance is not easy because they have to provide training and knowledge to farmers on how to grow superior rubber, it looks simple, but there are several ways that should be known to farmers such as fertilization and pest control.

In addition, it was said that the community superior rubber plant is something new because they have so far only planted local rubber plants because superior rubber is expensive so they cannot afford it. The way people treat superior rubber seeds is still the same as topical rubber after they have been planted carefree. This will certainly affect the growth of superior rubber, therefore intensive assistance is needed, but it is a pity that the number of officers is still limited, I do not think it is possible to provide optimal assistance, especially remote planting location ".

The statement shows that the number of field officers responsible for assisting rubber farmers is still not in line with the number of farmers receiving rubber seeds. Observations so far indicate that the community has planted superior seeds provided by the North Kayong government, but lacked maintenance, so there are seeds that grow unevenly. This shows that despite the using superior seeds, rubber plants still need good maintenance.

The minimum number of field officers in supporting the superior rubber seeds assistance program was also stated by the Head of Simpang Hilir Sub-District that: " the number of plantation advisers allocated to provide socialization and assistance to rubber farmers in Simpang Hilir District is still very minimal, in the sense that it is not in balance with the workload to be carried out ".

From the description above, it is obtained that there are quite a lot of tasks to be carried out, while the number of extension workers available is insufficient, this condition will certainly affect the effectiveness of program implementation.

In addition to the number (quantity), an important aspect of field staff support in the implementation of superior rubber assistance programs is the quality or ability to assist farmers. Regarding the quality of the officer of the Head of the Forestry and Plantation Service of North Kayong Regency said that: "officers who are placed in each district to carry out assistance have good quality and ability in conducting counseling to farmers because they have an educational background in agriculture".

Based on this information shows that in terms of the quality of the accompanying officer assigned to assist has met the quality to deliver counseling about rubber farming.

\section{b. Facilities and infrastructure}

Regarding the facilities and infrastructure in the implementation of superior rubber assistance program of the North Kayong District Forestry and Plantation Service, from the results of the researchers' interview with the Head of the North Kayong District Forestry and Plantation Office gave a statement namely: "Infrastructure and facilities, of course, are very important in the implementation of superior rubber assistance programs, in terms of village infrastructure that naturally receives assistance, there must be land to plant the distributed rubber, while other suggestions in support of the program include the availability of fertilizers, medicines, and herbicides are for the maintenance of seeds planted to grow well ".

The results of the interview above show that facility and infrastructure support is an important aspect that must also be fulfilled for the superior rubber seeds assistance program to work properly. The first infrastructure to comply with is the availability of land to plant seeds, followed by facilities such as fertilizers, medicines, and other support facilities.

Regarding the availability of land in Simpang Hilir Sub-district, from the results of interviews with the Simpang Hilir Sub-District Head said that: "Regarding the availability of land, I think in Simpang Hilir Sub-district there is a lot of vacant lands that is underutilized so that with the help of these superior rubber seeds farmers can utilize the land empty to be productive by planting rubber."

The information from the interview with the Simpang Hilir Sub-District Head illustrates that in terms of land availability in Simpang Hilir strongly supports the Forestry and Plantation Service program. For example, in addition to providing benefits for farmers, also helps the government to utilize land that belongs to the community 
to be more productive. This condition is also consistent with the results of observations made by researchers showing that using superior rubber seedlings, part of the land that has not been used is now planted with superior rubber.

In an interview with the Chairman of the Farmer Group said: "Farmers are very grateful for the assistance of rubber seeds because for us it is very difficult to get superior rubber seeds. In addition, farmers are helped enough to be able to cultivate vacant land to be planted with rubber, land that was previously malfunctioning and only covered with shrubs and fronds of ferns has now become useful plantations even though it has not yet yielded results".

The statement by the chairman of the Farmer Group illustrates that the availability of the land they are very ready because farmers have a huge land. Nevertheless, talk about support infrastructure, however, the availability of agricultural land must also be supported by adequate infrastructure. In the sense that helps in the form of rubber seeds must be provided with seeds facilities in order to grow properly.

Regarding support facilities in the superior rubber seeds assistance program, the results of the interviews of investigators with field officers who also served as extension officers simultaneously indicate an assessment of support for the following suggestions: "From my observations, the support of the program is not yet fully ready, such as in the Simpang Hilir Sub-district there is no nursery plantation available so that all seeds are taken from outside the island, while facilities such as fertilizers, herbicides, and polybags are still very limited. The government provided the assistance, but the amount is limited, this condition is also exacerbated by the lack of community participation through farmer groups to provide these facilities, they still have a dependency from the government. The lack of support for these facilities has an impact on the inaccuracy of the program, especially for maintaining seeds".

Based on the information submitted by field officers who understand the problems of the program in the field in detail, this illustrates that the program of support for advice such as fertilizers, herbicides, and polybags is still missing. Indeed, in this superior rubber assistance program, the North Kayong District Forestry and Plantation Service also assist with fertilizers, herbicides, and polybags, but the amount is limited. In the interview above it was also revealed that the farmer who gets assistance is not participating enough in providing support for fertilizers, herbicides and polybags, thus affecting seeds maintenance quality.

Farmer participation is urgently needed in this program, government assistance in the form of superior rubber seeds recommended PB 260 clones should be supported by providing farmers with self-help through fertilizers, herbicides, and polybags. Awareness and understanding of these farmers are very important; the North Kayong District Government's good intentions of providing free assistance to superior rubber seeds should be supported by providing facilities that the government cannot achieve due to budget constraints. Community support for fertilizers and medicines will influence the successful implementation of superior rubber support programs,

Based on the results of the above research, the community should also participate independently to provide production facilities. Self-help can be achieved by donating energy, money, and materials while carrying out activities. The basis of self-reliance is the willingness of people, so care must be taken to ensure that it is free from pressure or coercion. The importance of community participation is intended to increase the sense that farmers belong to the program. It can even be said that the community is obliged to participate as a form of support because it has received assistance from the government.

\section{c. Financing}

Budgetary factors play an important role in the implementation of a policy; the availability of an adequate budget is very possible to implement the policy under the expected goals. Conversely, the lack of available budget will have a major impact on policy implementation failure.

The implementation of a superior rubber program by the North Kayong District Forestry and Plantation Office requires if necessary, adequate financial support. The funding support is intended to cover the purchase and maintenance of seeds, medicines, fertilizers, and operational field officers. The program can continue without sufficient financial support, but results will not be maximal.

Regarding funding support in the implementation of a superior rubber assistance program in the Simpang Hilir District, from the statement of the Head North Kayong District Forestry and Plantation Service, said: " In support of the superior rubber assistance program, the North Kayong District Forestry and Plantation Office has allocated \pm 300.000 .000 rupiahs per year, which is shared among all-district in North Kayong Regency that is considered worthy.

The lack of maximum funding support also has an impact on the fluency implementation of the rubber seedlings assistance program for farmers, one of which is the availability of seeds given to farmers, because the budget is limited so that the seeds given are also limited and not all farmers get the seeds. In addition to funding fertilizers, and medicines are also limited in number and not given sustainably to farmers.

The lack of financial support also impacts the fluency of field staff in providing assistance and counseling to farmers. As stated by Field Officers who provide information that: "when providing counseling and assistance to farmers cannot be maximized because of limited funds for operational field officers, in particular, the limited 
number of officers and also the remote range of village".

Based on this information, it appears that budget constraints in the North Kayong District Forestry and Plantation Service's superior rubber assistance program also affected the fluency functioning of officers in helping farmers. Officials in the implementation of the assistance should be encouraged under the tasks that have been carried out, but budgetary constraints may cause a lack of incentives for officers.

In a situation where farmers' knowledge is still low, enlargement must be carried out intensively. Coaching and guiding field workers to farmers as a target group so that they have sufficient knowledge and skills about rubber cultivation techniques. With sufficient knowledge and skills, rubber farmers are expected to properly develop and maintain their plantations.

\section{d. Information}

The information takes two forms when implementing policy. First, information on how to implement the policy. Implementers should know what to do when they are instructed to take action. Secondly, information on the compliance data of the implementers of the governmental rules and regulations. When executing a superior rubber assistance program in the Simpang Hilir District, executive officers should have clear information and data on matters related to the technical implementation of the program.

Regarding information resources in the implementation of a superior rubber assistance program by the North Kayong Regency Forestry and Plantation Service Office at Rantau Panjang Village, Simpang Hilir District, the Head of the North Kayong District Forestry and Plantation Office stated: "the source of information in the implementation of a superior rubber assistance program is good enough, the officers whit his capacity to implement the program is following the applicable provisions".

The superior rubber assistance program implemented by the North Kayong District Forestry and Plantation Office does not contain a variety of complicated and difficult to understand provisions for officers in the field so that the program has been running so far without any doubt from the officers. In implementing the program so far, it has been supported by field officers competent in agricultural extension. The quality aspect of agricultural extension is related to the competence and skills required to advise farmers. An absolute ability of an agricultural teacher, because an extensionist must know different information in agriculture. In addition, it is not only limited to the transfer of agricultural information but also the correct demonstration of agricultural techniques to farmers, therefore it is also necessary to transfer and demonstrate agricultural techniques. This means that the ability of an agricultural instructor is something that the agricultural instructor must master.

In order to identify the information needs in the implementation of the program, the results of interviews with field officers explained that: "If the field officer does not have a problem with the necessary information, but the information is needed for the farmers because they are the ones those seeking help with sowing. Community information is still very limited because knowledge of superior rubber cultivation is still very minimal ".

The results of the interview showed that it is important to help provide information to farmers so that they can grow seeds properly.

\subsection{Disposition}

The tendency of implementing policy is the third factor that has important consequences for effective policy implementation. Given the importance of trends for effective policy implementation, there will be an impact of these trends in their implementation of the policy. According to Edwards, the impact of the trends is policies are actually implemented effectively because they have the support of the policy implementers, but those other policies may directly conflict with the views of those implementing the policy or the personal and organizational interests of the implementers. Due to trends that hinder implementation, implementers do not agree with the substance of policy. That implementation is hampered by very complex circumstances.

Commitment is an important capital that must be owned by the executor. If the implementer has a good commitment, he can implement the policy as the policymaker wishes. Conversely, if the implementer has a different attitude or perspective than the policymaker, the policy implementation process will not be effective. Involvement is also related to the implementer's response to the policy, the treatment of the policy, and the implementer's value preferences.

Regarding the motivation and commitment of officers in implementing a superior rubber assistance program to farmers in Rantau Panjang Village, Simpang Hilir District, the results of an interview conducted by the researcher with the Head of the Forestry and Plantation Office of North Kayong District explained as follows: "The superior rubber assistance program conducted by the Forestry and Plantation Office is one form of efforts to realize the vision of the Forestry and Plantation Office, namely the Realization of Sustainable Forestry and Plantation Optimization for Community Welfare so that the department and officers in the field are very committed to implementing this program as well as possible to improve the welfare of rural communities ".

Based on the information submitted by the Head of the Forestry and Plantation Service, it shows that his party is very committed to implementing the program well. The commitment is also inseparable from the assistance program of superior rubber seeds which is a program of the Forestry and Plantation Office, meaning that it is not 
a program of the central government. The program was made against the background of the need for seeds assistance to develop rubber plantations that have great potential in the North Kayong Regency.

Even though it is in a small scope and limited financial resources, the Forestry and Plantation Agency through the apparatus in the field is very active in supporting the program, not only providing seed assistance but also actively providing assistance and counseling to farmers. This is as stated by Field Extension Officers who assist farmers by providing information, said: "I am quite enthusiastic about welcoming and implementing superior rubber assistance programs from the Forestry and Plantation Office, because the seeds given are a superior one, especially at the time counseling, the community's enthusiasm was quite high because it was the first time they had received superior rubber seeds from the government ".

A statement from the results of the interview with the field extension officer above shows that the officers are already motivated and committed to supporting the implementation of the Forestry and Plantation Services Program. Especially when this is related to limited program support resources and regional conditions that have not been supported by adequate infrastructure. The existence of a strong commitment and a clear policy of the Forestry and Plantation Office is the main supporting factors in the development of plantations, in particular the development of superior rubber plantations.

The high commitment and motivation of the North Kayong District Forestry and Plantation Office certainly cannot be used as a reference when providing implementer decisions to a program. In order to know the objective conditions for disposition of officers in the superior rubber seeds assistance program, therefore required information from relevant parties including local farmers.

In an interview with the Head of Simpang Hilir Sub-district, who assessed the motivation of the officers in providing assistance to farmer groups as follows; "In my opinion, field extension officers are quite active in providing assistance and counseling to farmers. Officers help farmers if they have problems managing seeds, and what is very important is that field officers continue to provide farmers with good farming techniques."

In line with the statement of the Simpang Hilir Sub-District Head, the Chairperson of the Rantau Panjang Village Farmer Group gave the following information: "The assistance provided by field officers is very good, officers are willing to provide information or help farmers when experiencing difficulties. However, because the number of officers is limited, the intensity of counseling is also less than optimal ".

Based on the information from the two informants, it is illustrated that the field officer, as a program executor, has demonstrated a strong commitment to supporting the implementation of the superior rubber seeds assistance program. Although in the eyes of the farmers the intensity of the counseling given was still not optimal, this is due to the lack of field extension officers.

So far, it seems that support and commitment from the government are still not maximal in increasing the number of accompanying officers, this is evidenced by the lack of farmer groups getting escort and periodic and continuous mentoring by officers on the technical preparation of seeds, planting to maintenance so that rubber farmers do not get good information from in terms of cultivation, and garden management. Ideally, every 1 or 2 weeks a meeting is held to see the development of seed management carried out by farmer groups, but sometimes meetings with farmer groups only take place once a month. Guidance and assistance are still lacking continuously, so that farmer groups still lack knowledge (how to plant, fertilize, and care) for the maintenance of superior rubber seedlings.

Nevertheless, the deployment of the field officers is not accompanied by incentives from the Forestry and Plantation Office. The high workload and important role have not been matched by rewards in the form of adequate compensation and facilities. Ultimately, this condition is also inseparable from minimal budget support.

\subsection{Bureaucratic Structure}

The bureaucratic structure is an important instrument in policy implementation. Bureaucratic structure describes the direction of the relationship, the command line, and the pattern of coordination between work units in the organization. Aspects related to the bureaucratic structure include the existence of standard operating procedures (SOP). Then there is fragmentation, namely the distribution of work patterns between departments within the organization and the availability of clear rules regarding the authority and responsibility of officers' activities across multiple work units.

\section{a. Standard Operational Procedure (SOP)}

SOP is an organizational tool whose task to provide a standardized action reference to policy implementers, so that each policy implementer will implement coordinated and targeted actions to achieve policy. Although the means to implement policy are sufficient and the implementers know what and how to do it, and have a desire to do. The implementation may still not be effective due to the inefficiency of the existing bureaucratic structure. The important things in the bureaucratic structure include the effectiveness of the organizational structure, division of labor, coordination, and standards of success.

Regarding the SOP in the implementation of the superior rubber seeds assistance program to farmers in Rantau Panjang Village, Simpang Hilir District, the results of an interview with the Head of the Forestry and 
Plantation Service of North Kayong District gave the following explanation: "the form of superior rubber seeds assistance program implemented by the Forestry and Plantation Service North Kayong Regency to farmer groups is in the form of grants that are distributed directly to farmer groups without the government receiving compensation. The mechanism comes from the community through farmer group proposals addressed to the North Kayong District Forestry and Plantation Service, then the North Kayong District Forestry and Plantation Service accommodate the proposal through the plantation sector work plan. "

This statement illustrates that the assistance program for superior rubber seeds carried out by the North Kayong District Forestry and Plantation Service did not go through a long bureaucracy. In addition, the assistance provided is in the form of grants, then seen from the scope of the program the area is directly implemented at the district level by the Forestry and Plantation Service of North Kayong Regency to each selected village. The mechanism for submitting assistance is not difficult, in the sense that it does not go through procedures and requirements that are burdensome to the community. Another important thing regarding the ease in the superior rubber assistance program is that assistance was given in the form of seeds and no money. To minimize the potential for misappropriation of funds by relevant persons.

Meanwhile, the results of field officer interviews said that: "the organizational structure in this program falls directly under the Forestry and Plantation Service of North Kayong Regency so that the range of control and coordination between officers in each village is not too difficult, several obstacles will be easier to coordinate directly by the North Kayong District Forestry and Plantation Office. "

Based on this information, it appears that from the organizational structure aspect, a superior rubber assistance program is very good at supporting the fluency implementation of the program by officers in the field. However, this is not without problems, there is standard operational procedures that incriminates the community to get the assistance of these seeds. In Rantau Panjang Village, not all communities have received seed assistance because it collided with the readiness of the farmers with land for cultivation.

This condition is certainly very influential on the process of seed distribution, where the observations of researchers show that some farmers who get assistance not ready with the land to plant the seeds, so the assistance they receive is not planted, but they sell it. This condition clearly shows that the SOP in the superior rubber seeds assistance program by the Forestry and Plantation Service of North Kayong Regency has not been well structured.

\section{b. Fragmentation}

Fragmentation is the distribution of patterns of work relations between parts of an organization and the availability of clear rules regarding the authority and responsibility of the officers' activities among several work units. Fragmentation in the superior rubber assistance program by the North Kayong District Forestry and Plantation Office is the division of roles of each work unit and authority in the implementation of the program. Regarding the division of roles and authority in the superior rubber assistance program, the Head of the North Kayong District Forestry and Plantation Service explained that: "the division of in the superior rubber assistance program is very clear, so there is no tossing of responsibility and authority at the time of carrying out the roles".

Meanwhile the results of interviews with field officers said that: "so far there have not been any problems regarding the division of work and authority all have proceeded following the provisions".

The same thing is also reflected in the observations of researchers which show that the pattern of relationships between work units has been well established in the implementation of superior rubber assistance programs. Coordination between parties is going well. The results of this study indicate that there are no problems in terms of fragmentation that can interfere with the implementation of the program.

\section{Conclusion.}

The conclusions of the discussion of the results of research into the implementation of superior rubber support programs by the Forestry and Plantation Office of North Kayong Regency are as follows:

a. The communications conducted to implement the superior rubber support program by the North Kayong District Forestry and Plantation Office have not been properly conducted, so it has an impact on the implementation of the program. This situation is evidenced by the lack of communication with the community, so that not all communities have received clear information about this superior rubber assistance program, especially on how to properly manage seeds.

b. Resources for implementing a superior rubber support program to farmers by the Kayong Utara District Forestry and Plantation Service are still lacking and hindering program implementation. These resources are the minimum number of field extension officials to advise and assist farmers in managing superior rubber seeds, in addition to the limited number of advisers, the implementation of superior rubber support programs is not supported by adequate facilities and infrastructures, in particular fertilizers and medicines, inadequate funding sources affecting the fulfillment of facilities and infrastructure, as well as operational field officers and rubber farmers do not have enough information from sources of information to properly manage seeds assistance. 
c. The commitment of policy implementers, namely field officers to conduct superior rubber seeds assistance programs in the Simpang Hilir District has been very good in providing assistance and counseling, but the results are not optimal as the number of officers is limited and not yet supported by adequate incentives.

d. The bureaucratic structure in the implementation of superior support programs for rubber seeds is already good because there is not too much control and the procedure for submitting assistance is not too complicated. However, the requirements for submitting assistance in the form of land availability have not been properly implemented as there are still recipients of assistance who are not ready for the land.

\section{The research recommendation}

Based on the conclusions of the research results, the researchers made several suggestions to make the implementation of superior rubber assistance programs by the North Kayong District Forestry and Plantation Service more efficient, including:

1. The addition of field extension officers by proposing recruitment formations to the North Kayong Regency Regional Office of Human Resources Agency, to make mentorship for farmers more effective, increasing farmers' knowledge of superior rubber plant cultivation, and be able to realize an independent farmer.

2. Increased budget allocation for superior rubber assistance programs as needed, by identifying all sources that affect the proper functioning of the program, such as the number of seeds, human resources, infrastructure (fertilizers and medicines), and the scope of field officers' activities.

3. Increase staff deployment by providing additional incentives following the workload performed and by providing other support facilities.

4. To anticipate assistance that is not on target, before the assistance is delivered, the officer must check the readiness of the farmers' land so that the farmers receiving the seeds are ready to manage the seeds.

\section{References}

Abidin, Said Zainal. (2004). Analisis Data Penelitian Kualitatif, Pemanfaatan Filosofi dan Metodologi kearah Penguasaan Model Aplikasi. Jakarta: Raja Grafindo Persada.

Dunn, William. N. 2002). Analisia Kebijaksanaan Publik. Yogyakarta: Hanindita.

Dimock. E. 1998. Understandinng Public Policy. New jersey: Prentice Hall

Gaffar, Afan. (1998). Publik Policy: State Of The Disipline, Models and Process. Yogyakarta: Pasca Sarjana Universitas Gajah Mada.

Gito, Sudarmono, Indriyo dan Agus, Mulyono. (1997). Prinsip-Prinsip Dasar Manajemen. Yogyakarta: BPEF. Islamy, M. Irfan. (2001). Prinsip-Prinsip Perumusan Kebijakan Negara. Jakarta: Buni Aksara.

Jones, O Charles. (2000). Pengantar Kebijakan Publik, Terjemahan Riky Istamto. Jakarta: Raja Grafio Persada. Mazmania, Daniel H. And Paul A. Sabatier. (1998). Implementation and Public Policy. New York: Harper Collins. Miles, Matthew B dan Huberman A, Michael. (1992). Analisis Data Kualitatif. Jakarta: Universitas Indonesia. Moleong, Lexy J.M.A. (2007). Metodologi Penelitian Kualitatif. Bandung: Remaja Rosdakarya.

Nugroho, D Riant.( 2003). Kebijakan Publik, Formulasi, Implementasi dan Evaluasi. Jakarta: Gramedia.

Putra, Fadillah. (2001). Pradikma Kritis Dalam Studi Kebijakan Publik. Yogyakarta: Pustaka Pelajar Offet.

Purwanto, Agus Erwan \& Sulistyastuti, Ratih, Dyah. (2012). Implementasi Kebijakan Publik: Konsep dan Aplikasinya di Indonesia. Yogyakarta: Gava Media.

Ripley, Randal B, dan Franklin, Grace A. (1984). Policy Implementation and Bureaucracy. Chicago: The Dorsey Press.

Rusli, Budiman. 2003. Kebijakan Publik, Membangun Pelayanan Publik yang Responsif. Bandung: Hakim Publising.

Subarsono, AG. (2005). Analisis Kebijakan Publik: Konsep, Teori dan Aplikasi. Yogyakarta: Pustaka Pelajar.

Sunggono, Bambang. (1994). Hukum dan Kebijaksanaan Publik. Jakarta: Sinar Grafika.

Sugiyono. (2007). Memahami Penelitian Kualitatif. Bandung: Alfabeta.

Sumaryadi, I Nyoman. (2005). Evektivitas Implementasi Kebijakan Otonomi Daerah. Jakarta: Citra Utama.

Tachjan. (2006). Implementasi kebijakan publik. Bandung: AIPI \& Puslit KP2W Lemlit Unpad.

Wahab, A Solichin. (2002). Pengantar Analisis Kebijakan Negara. Jakarta: Reneka Cipta.

Wibawa, Samodra. (2000). Kebijaksanaan Publik Proses dan Analisis. Jakarta: Intermedia.

Widodo, Joko. (2007). Analisis Kebijakan Publik, Konsep dan Aplikasi. Analisis Proses Kebijakan Publik. Jakarta: Bayu Media.

Winarno. Budi, ( 2007). Teori dan Proses Kebijakan Publik. Yogyakarta: Pressindo. 